\title{
DAMPAK PEMBANGUNAN BREAKWATER TERHADAP STRUKTUR KOMUNITAS POLYCHAETA DI PESISIR PANTAI MANOKWARI, PAPUA BARAT
}

\author{
The Impact of Breakwaters Development to the Structures Community of Polychaeta \\ in the Coastal of Manokwari, West Papua
}

Diana Elsa Albita Wambrauw, Keliopas Krey, Sita Ratnawati*

Program Studi Biologi, Fakultas Matematika dan Ilmu Pengetahuan Alam, Universitas Papua, Manokwari 98314, Indonesia.

*Korespondensi: itta.sita@gmail.com

\begin{abstract}
Breakwater is a small structures designed to protect coastal area from extremely sea waves exposure. The breakwater has been used in many coastal area at various town in Papua include Manokwari Regency, West Papua Province. Breakwaters designed at Manokwari has been reduce the intensity of wave action in inshore waters. Moreover, the breakwater also reduce coastal erosion and provide safe harbourage for local fishing. Same with the others, the breakwater on the coast of Manokwari also contact with the substrate directly, which is a habitat for Polychaeta. The lack of research data and information on Polychaeta in the Papua Sea encourages this research must be done. The purpose of this research is to identify the spesies of Polychaeta and analyze the impact of breakwater to the community structure of Polychaeta. This research conducted on March to June 2018 focus on six station of five beach with breakwater at the coastal of Manokwari, West Papua i.e. Abasi, Pasir Putih, Wosi, Andai and Mansinam Island. The line transect quadran method were use to collect sample of the Polychaeta. Total 64 sample of Polychaeta was collecting and identified. Approximately 17 spesies of Polychaeta (i.e. seven orders, nine of families and 14 genera) already identified. Based on ANOVA and BNt tests, the breakwater development has significantly impacte to the structure community of Polychaeta on the coastal of Manokwari.
\end{abstract}

\begin{abstract}
ABSTRAK
Breakwater atau pemecah gelombang merupakan struktur kecil yang didesain untuk melindungi area pesisir pantai dari paparan gelombang air laut yang ekstrim. Sama dengan lainnya, breakwater di pesisir pantai Manokwari juga bersentuhan langsung dengan substrat, yang merupakan habitat cacing laut, Polychaeta. Minimnya data penelitian dan informasi tentang Polychaeta di laut Papua mendorong penelitian ini dilakukan dengan tujuan mengidentifikasi spesies Polychaeta dan menganalisa dampak yang ditimbulkan dari breakwater terhadap struktur komunitas cacing taksa cacing laut ini. Penelitian ini dilaksanakan pada bulan Maret hingga Juni 2018 yang dipusatkan pada enam stasiun di lima pantai yang terdapat breakwater, yaitu pantai Abasi, Pasir Putih, Wosi, Andai dan pantai Pulau Mansinam. Garis transek kuadran sebagai metode pengambilan sampel Polychaeta. Sebanyak 64 sampel telah dikoleksi dan berhasil dikenali 17 spesies Polychaeta yang terbagi dalam tujuh ordo, sembilan familli dan 14 genus. Berdasarkan uji ANOVA dan Uji BNt menunjukan keselarasan pembangunan breakwater berdampak signifikan terhadap struktur komunitas Polychaeta di pesisir pantai Manokwari.
\end{abstract}

Keywords: Breakwater, Coastal, Polychaeta, Manokwari, West Papua

\section{PENDAHULUAN}

Manokwari, ibu kota Provinsi Papua Barat, sebagian besar wilayahnya dikelilingi oleh laut sehingga wilayah ini memiliki garis pantai yang

relatif panjang. Pesisir pantai sangat rentan terhadap kerusakan yang diakibatkan oleh gelombang air laut (Putra et al., 2013). Faktanya 
wilayah pesisir sejak dulu telah digunakan sebagai pemukiman penduduk, tempat wisata hingga perindustrian sehingga perlu dilindungi. Terkait itu, pemerintah terus berupaya melakukan penanggulan-penanggulan pesisir pantai untuk menanggulangi aktifitas gelombang ekstirm dengan membangun pengaman pantai berupa pemecah gelombang lepas pantai (Ariani et al., 2013).

Pemecah gelombang atau breakwater merupakan struktur tanggul kecil yang didesain sebagai pemecah sekaligus penghambat gelombang air laut yang kerap menghantam bibir pantai dan menyebabkan abrasi luar biasa hingga merusak infrastruktur. Bangunan ini digunakan untuk melindungi wilayah perairan pesisir pantai maupun perairan pelabuhan dari ancaman gelombang (Ariani et al., 2013; Refi, 2013).

Bangunan breakwater dibangun sejajar garis pantai dengan jarak beberapa meter dari garis pantai untuk memisahkan daerah laut lepas dengan garis pantai (Putra et al., 2013). Keberadaan dari bangunan breakwater telah mengubah struktur pantai. Hal ini tentunya dapat berdampak pada komunitas organisme hidup yang berada di area tersebut, walaupun dampak yang ditimbulkan oleh breakwater belum diketahui secara pasti.

Salah satu komunitas bentik laut yaitu Polychaeta (Shin et al., 2004), merupakan salah satu kelas terbesar dalam filum Annelida (Grzimek's, 2004). Filum Annelida terdiri dari tiga class besar yaitu Polychaeta (umumnya di laut), Oligochaeta (umumnya di air tawar atau teresterial) dan Hirudinea (lintah) (Moore, 2006; Fauchald, 1977). Polychaeta merupakan class cacing yang umumnya hidup di laut sehingga dikenal sebagai cacing laut, walaupun tidak semua cacing laut termasuk class Polychaeta (Munairi dan Abida, 2012).

Polychaeta memiliki pergerakan yang lambat dan bersifat sesil atau diam. Hal ini menyebabkan aktivitasnya dapat dipengaruhi langsung oleh bahan pencemar yang masuk ke perairan (Shin et al., 2004). Walaupun demikian peranan Polychaeta bagi organisme lain dan juga lingkungannya cukup vital.

Peran Polychaeta dalam rantai makanan sebagai sumber pakan alami bagi hewan-hewan air yang berada di lingkungannya, misalnya ikan dan udang (Tomassetti \& Porrello, 2005; Rasidi, 2012). Polychaaeta juga memiliki peranan penting dalam menjaga stabilitas sedimen dasar laut serta proses dekomposisi bahan organik pada ekosistem mangrove (Murugesan et al., 2016). Selain berperan sebagai indikator kesuburan suatu perairan, Polychaeta juga berperan dalam menjaga kesuburan pada ekosistem perairan yang secara tidak langsung dapat diperkirakan dengan mengukur kelimpahan, biomassa serta komposisi spesies (Priandayani et al., 2017).

Tampaknya formasi substrat (sedimen) di dasar pesisir menjadi faktor pembatas distribusi Polychaeta. Formasi sedimen ini secara ekologi menjadi habitat Polychaeta dan makrobentik lainnya. Fromasi sedimen seperti ukuran partikel, konsentrasi bahan organik dan ketersediaan makanan (Kari, 2002) sebagai faktor penting yang berperan dalam sebaran makrobentik laut. Faktor lain yang juga berperan dalam sebaran adalah kedalaman air (Gholizadeh et al., 2012). Alga dan bahan organik merupakan sumber makanan utama bagi organisme bentik, makanan tersebut masuk melalui run off dari daratan (Sudaravarman et al., 2012), salah satunya berasal dari sungai yang bermuara di pesisir pantai.

Kompleksitas ekologi, struktur komunitas, dan peran penting Polychaeta mungkin akan terganggu oleh pembangunan breakwater. Fenomena biologi ini diperparah lagi dengan tidak tersedianya data maupun informasi tentang taksonomi Polychaeta dari pesisir pantai Papua. Berdasarkan uraian ini, maka tujuan penelitian ini adalah mengindetifikasi spesies Polychaeta, menganalisa distribusi spasial dan dampak negativ yang ditimbulkan oleh pembangunan breakwater terhadap keberlangsungan hidup Polychaeta di pesisir pantai Manokwari.

\section{METODE}

\section{Lokasi Pengambilan Sampel}

Penelitian ini berlangsung sejak Maret hingga Juni 2018. Pengambilan sampel Polychaeta dipusatkan pada enam stasiun pengamatan di pesisir pantai Manokwari (Gambar 1) yakni Pantai Abasi (stasiun I), Pasir Putih (stasiun II), Wosi (stasiun III), Andai (stasiun IV), dan Pantai Pulau Mansinam (stasiun $\mathrm{V}$, dan VI). 


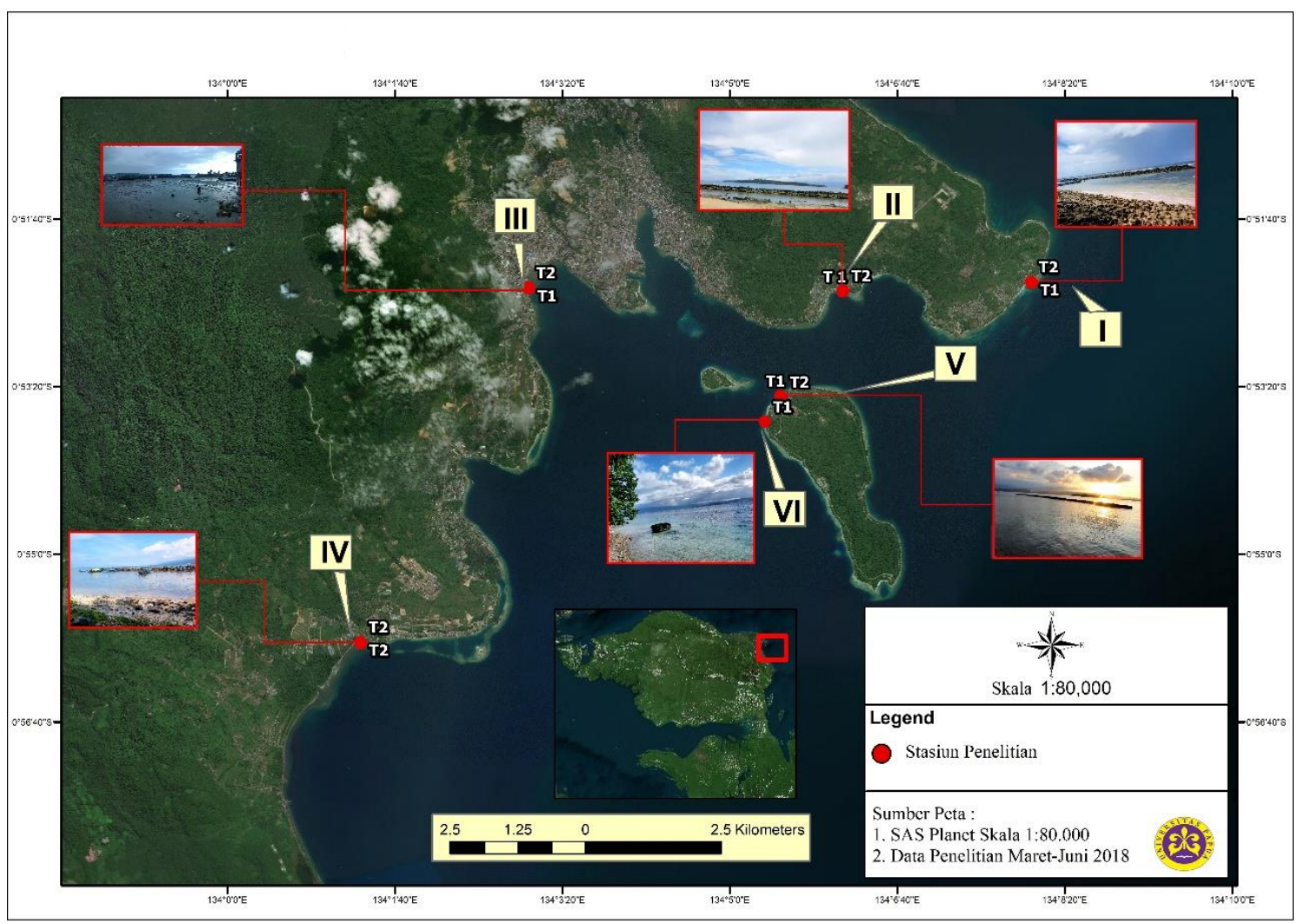

Gambar 1. Enam stasiun pengamatan yang terdapat breakwater: Pantai Abasi (stasiun I); Pantai Pasir Putih (stasiun II); Pantai Wosi (stasiun III); Pantai Andai (stasiun IV); Pantai Pulau Mansinam (stasiun V dan VI)

\section{Pengambilan Sampel Polychaeta}

Pengambilan sampel

menggunakan metode garis transek kuadran menurut Wowor et al., (2016). Arah transek dirintis sejajar dengan bangunan breakwater (Gambar 2). Transek di tempatkan pada titik sampling yang telah ditentukan, di sisi depan dan belakang dari bangunan breakwater. Transek dibuat sepanjang $100 \mathrm{~m}$, menggunakan rol meter dan memberi penanda (kayu, tali rafia dan sterofom) pada titik-titik plot. Plot (kuadran) berukuran 30 x $30 \mathrm{~cm}$ (Qudratullah, 2013), berjumlah 10 plot.

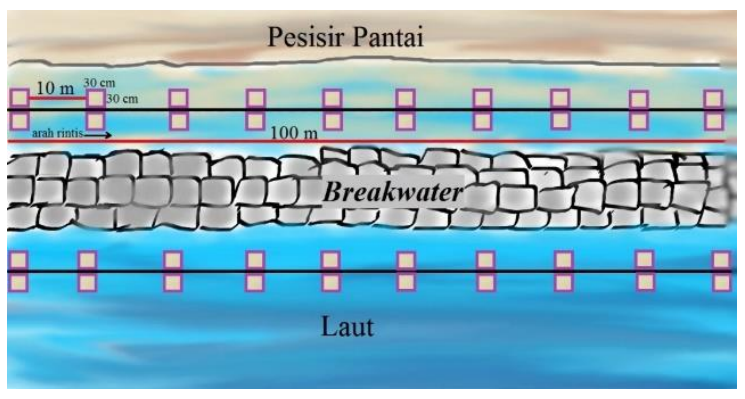

Gambar 2. Sketsa arah peletakan transek
Pengambilan sampel Polychaeta di setiap stasiun dilakukan pada saat air laut surut. Pengambilan sampel di lapangan dikerjakan dengan berjalan kaki ketika air sedang surut maupun dengan snorkeling, ketika terdapat tempat-tempat dengan kedalaman air lebih dari $30 \mathrm{~cm}$ (Satrya et al., 2012). Menggunakan gloves pada saat melakukan proses penyamplingan pada substrat berupa karang.

Proses penyamplingan pada setiap plot di setiap stasiun dilakukan penyesuaian dengan kondisi di lapangan. Pada plot terdapat substrat berupa karang yang terendam air, sehingga penyamplingan menggunakan besi pengorek. Sedangkan substrat berupa pasir dan lumpur (plot tidak terendam air), dilakukan proses penggalian menggunakan sekop. Namun, untuk plot sampling berada pada kedalaman air lebih dari 30 cm maka digunakan alat corer (terkecuali substrat berupa karang) (Fauchald, 1977). Proses penggalian maupun membenamkan corer dilakukan sedalam 5-20 cm (Romadhoni dan Aunurohim 2013; Fauchald, 1977). Substrat dari 
hasil galian dan membenamkan corer disaring menggunakan saringan.

Selanjutnya mencatat posisi geografis lokasi pengamatan dengan menggunakan GPS. Teknik pengambilan sampel dilakukan secara acak (Priandayani et al., 2017) untuk menentukan arah plot ke kiri atau kanan. Bingkai kuadran berukuran 30 x $30 \mathrm{~cm}$ diletakan di titik plot, pada saat melakukan proses sampling.

\section{Penanganan Sampel}

Sampel yang telah diperoleh dari setiap plot dimasukkan ke dalam plastik spesimen yang telah dilubangi. Kemudian memberi label (data lapangan) pada spesimen yang terdiri dari nama lokasi (stasiun), tanggal koleksi serta titik koordinat dan dimasukkan ke dalam botol sampel. Setelah proses penyamplingan selesai, dilakukan proses dokumentasi menggunakan kamera digital.

Fiksasi sampel Polychaeta dilakukan di dalam botol sampel yang telah berisi formalin 5\% (Sahidin dan Wardiatno, 2016). Botol diletakkan dengan posisi horizontal (melintang) sehingga tubuh Polychaeta didalamnya tetap lurus (tidak membengkok) untuk mempermudah proses identifikasi. Spesimen kemudian dibawa ke laboratorium Zoologi Universitas Papua untuk diidentifikasi.

\section{Analisa Data}

\section{Identifikasi Polychaeta}

Identifikasi Polychaeta dilakukan sampai dengan takson terendah yaitu genus, dengan berpedoman kunci identifikasi menurut Fauchald (1977) dan Day (1967).

\section{Analisa Struktur Komunitas Polychaeta}

Analisa struktur komunitas Polychaeta dilakukan dengan perhitungan data kuantitatif: indeks keanekaragaman, indeks kemerataan, indeks kesamaan, kepadatan dan dominasi yang diolah dan dianalisis menggunakan software Microsoft Excel 2010. Data kuantitatif digunakan untuk uji ANOVA (Analysis of variance) dan Uji BNt (Beda Nyata terkecil). Perhitungan data kuantitatif menggunakan persamaan yang ditinjau berdasarkan Romimohtarto dan Juwana (2007); Romadhoni dan Aunurohim (2013).

\section{Analisa Distribusi Spasial}

Seluruh hasil temuan Polychaeta direkam letak geografisnya dengan menggunakan GPS. Data-data rekaman ini selanjutnya dianalisa secara baik dengan bantuan aplikasi ArcGIS v.10.3 dan SAS Planet v. 171130.9738 Nightly. Mengingat pentingnya pemaparan visual hasil penelitian ini maka seluruhnya spesies Polychaeta yang teridentifikasi menghuni sedimen pesisir pantai Manokwari dipetakan dalam peta distribusi.

\section{HASIL DAN PEMBAHASAN \\ Identifikasi Polychaeta}

Berdasarkan hasil identifikasi 64 sampel Polychaeta ditemukan sebanyak 17 spesies yang terbagi dalam tujuh ordo, sembilan familli dan 14 genus. Hasil temuan dalam penelitian ini menunjukan bahwa daerah stasiun III (breakwater Wosi) memiliki spesies tertinggi jika dibandingkan dengan lima stasiun lainnya. Secara detil data Polychaeta yang ditemukan dan teridentifikasi di lima breakwater dan satu stasiun pembanding, ditampilkan pada Tabel 1.

Hasil temuan penelitian ini juga menunjukan bahwa distribusi populasi Polychaeta di pesisir pantai Manokwari cukup luas. Populasi yang memiliki distribusi luas yakni Glycera sp.2 yang ditemukan di stasiun II, III, IV dan VI serta Nereis sp.1 yang ditemukan di stasiun I, V dan VI. Eunicidae adalah familli dari Polychaeta dengan temuan spesiesnya paling banyak yaitu Arabella sp., Diopatra sp.1, Diopatra sp.2 dan Onuphis sp. (Gambar 3).

\section{Struktur Komunitas Polychaeta}

Indeks keanekaragaman pada stasiun I, II, IV dan $\mathrm{V}$ masuk dalam kategori rendah. Sedangkan stasiun III dan VI termasuk dalam kategori sedang (Tabel 2). Fenomena ini diduga disebabkan oleh perbedaan kondisi biofisik dan kimia habitat. Semakin buruk kondisi suatu perairan akan berdampak pada rendahnya keanekaragaman, karena hanya sedikit spesies yang dapat toleran dan beradaptasi terhadap kondisi perairan yang mengalami tekanan ekologis secara terus menerus (Mentarijuita et al. 2014). Setiap spesies memiliki rentang atau daya toleransi tersendiri dalam beradaptasi dengan 
kualitas perairan (Tobing, 2009). Junardi dan Wardoyo (2008) mengungkapkan bahwa nilai indeks keanekaragaman menggambarkan suatu kondisi adanya keterkaitan dengan fungsi masing-masing spesies terhadap kelestarian dan daya dukung ekosistem. Indeks keanekaragaman spesies juga dipengaruhi oleh tingkat dominasi suatu spesies. Stasiun I memiliki nilai dominasi yang tinggi karena didominasi oleh satu spesies yaitu Nereis sp.1, tetapi memiliki nilai keanekaragaman yang rendah. Hasil ini sesuai dengan pernyataan Junardi dan Wardoyo (2008).
Indeks kemerataan (J) mengasumsikan bahwa indeks kemerataan berbanding lurus dengan indeks keanekaragaman (H'). Insafitri (2010) mengungkapkan bahwa jika semakin kecil indeks keanekaragaman maka indeks kemerataan juga akan semakin kecil, yang mengisyaratkan bahwa terdapat dominasi suatu spesies terhadap spesies lain. Indeks kemerataan dibagi menjadi 3 kategori yaitu $\mathrm{J}<0.4$ kemerataan populasi kecil, $0.4<\mathrm{J}<0.6$ kemerataan populasi sedang, dan $\mathrm{J}>0.6$ kemerataan populasi tinggi (Insafitri, 2010).

Tabel 1. Hasil identifikasi Polychaeta pada enam stasiun pengamatan

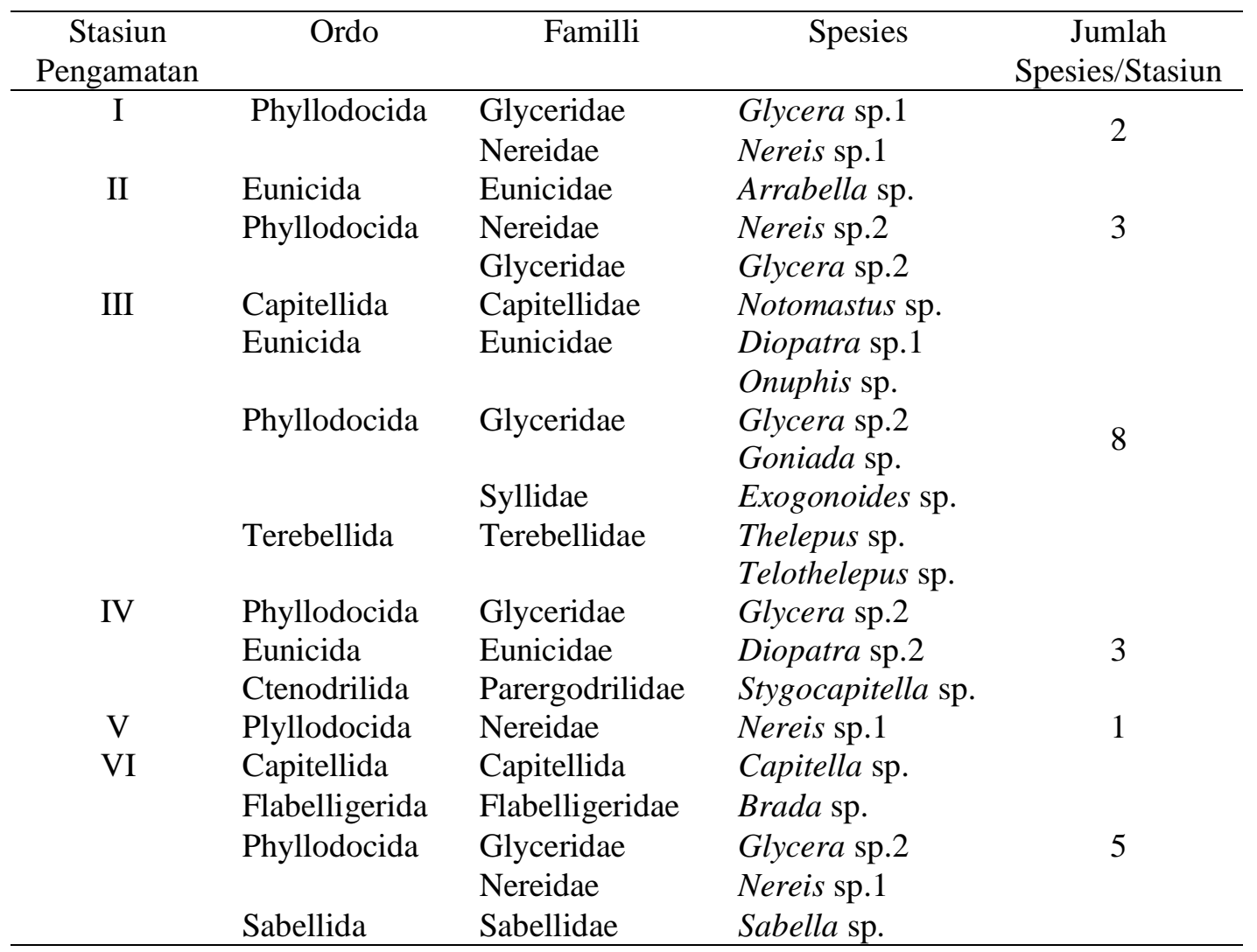

Tabel 2. Hasil analisa keanekaragaman (H'), kemerataan (J), kepadatan (D), dan dominasi (C) spesies Polychaeta di enam stasiun pengamatan

\begin{tabular}{ccccccc}
\hline Stasiun & $\begin{array}{c}\text { Jumlah } \\
\text { Spesies }\end{array}$ & $\begin{array}{c}\text { Jumlah } \\
\text { Individu }\end{array}$ & H' & J & D & C \\
\hline I & 2 & 6 & 0.45 & 0.65 & 0.66 & 0.72 \\
II & 3 & 8 & 0.73 & 0.66 & 0.88 & 0.59 \\
III & 8 & 22 & 1.67 & 0.86 & 2.44 & 0.24 \\
IV & 3 & 11 & 0.60 & 0.54 & 1.22 & 0.68 \\
V & 1 & 1 & 0.36 & 0 & 0.11 & 0.11 \\
VI & 5 & 16 & 1.12 & 0.70 & 1.77 & 0.43 \\
\hline
\end{tabular}




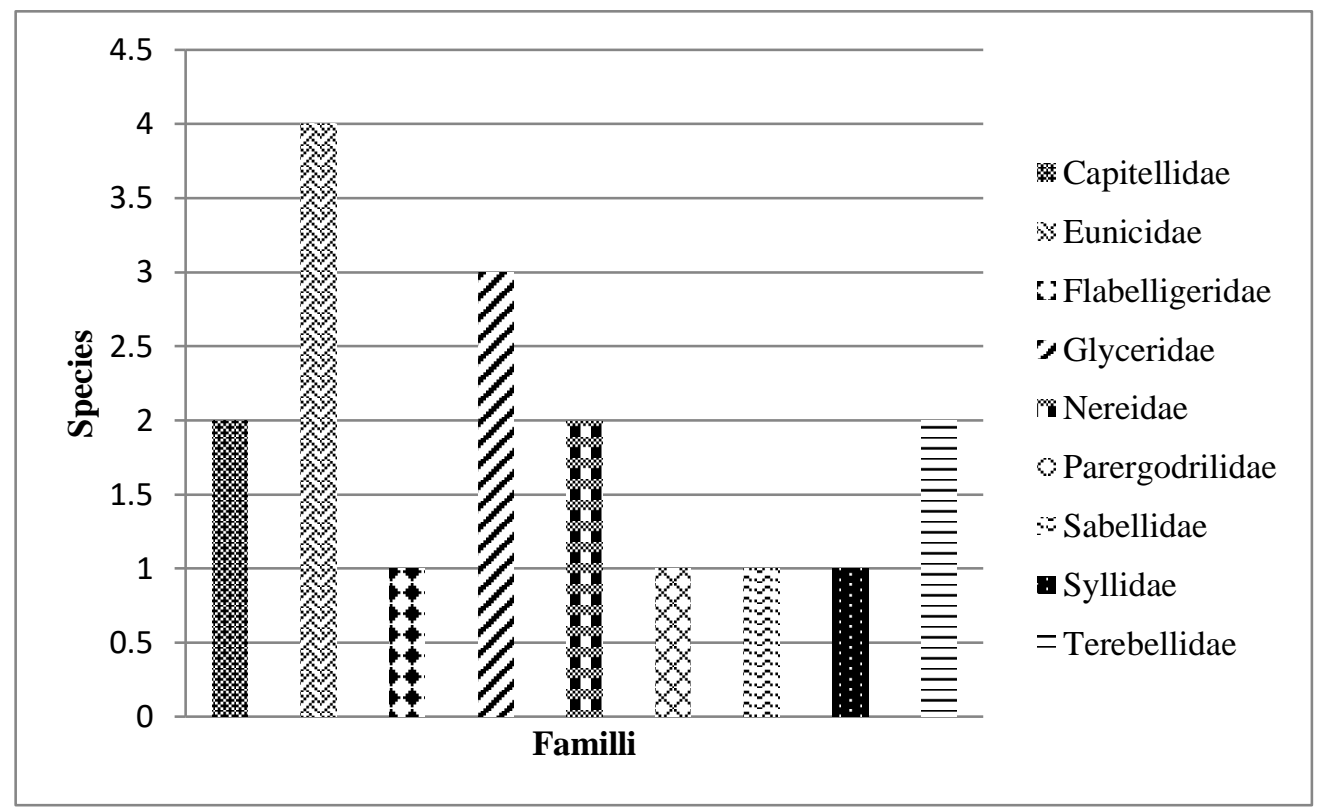

Gambar 3. Jumlah spesies Polychaeta per familli

Tabel 1. Rata-rata kualitas fisik dan kimia perairan setiap stasiun dengan perbandingan baku mutu air laut untuk biota laut menurut KepMen. LH No. 51 tahun 2004

\begin{tabular}{lccccccc}
\hline \multicolumn{1}{c}{\begin{tabular}{c} 
Parameter Fisik Kima \\
\multicolumn{1}{c}{ Perairan }
\end{tabular}} & I & II & III & IV & V & VI & KepMen \\
\cline { 2 - 6 } & LH 51 \\
\hline Suhu $\left({ }^{\circ} \mathrm{C}\right)$ & 29.4 & 30.25 & 32.35 & 30 & 29.7 & 28.7 & $28-32$ \\
Kecerahan Air $(\mathrm{m})$ & 2.1 & 1.65 & 0.65 & 0.47 & 2.15 & 1.15 & $>3$ \\
Kecepatan Arus (m/s) & 0.07 & 0.28 & 1.75 & 1.5 & 0.24 & 0.1 & - \\
pH & 8 & 8 & 7 & 8 & 8 & 8 & $7-8.5$ \\
DO $(\mathrm{mg} / \mathrm{L})$ & 5.9 & 4.5 & 10.6 & 5 & 4.95 & 4.9 & $>5$ \\
Suhu Do $\left({ }^{\circ} \mathrm{C}\right)$ & 30.85 & 32.65 & 32.9 & 32.85 & 31.35 & 31.4 & - \\
Salinitas $(\%)$ & 34 & 32 & 30 & 32 & 33 & 33 & $33-34$ \\
Kedalaman $(\mathrm{m})$ & 2.3 & 1.77 & 1.15 & 1.35 & 2.15 & 1.15 & - \\
\hline
\end{tabular}

\section{Analisis Dampak Pembangunan Breakwater terhadap Struktur Komunitas Polychaeta}

Kualitas perairan terukur melalui parameter fisika (suhu, kecerahan air, kecepatan arus dan kedalaman), kimia ( $\mathrm{pH}$, DO, suhu DO dan salinitas) (Tabel 3) maupun substrat dan biotik digunakan untuk menganalisa dampak dari breakwater terhadap struktur komunitas Polychaeta. Analisis struktur komunitas meliputi indeks keanekaragaman, indeks kemerataan, kepadatan dan dominansi Polychaeta antara stasiun juga dilakukan untuk mempelajari fenomena kondisi substrat akibat pembangunan breakwater.

Suhu di keenam stasiun berkisar antara 28.7-32.35 ${ }^{\circ} \mathrm{C}$ dan masih termasuk dalam kategori yang baik berdasarkan baku mutu air laut. Nilai kecerahan air di keenam stasiun $<3 \mathrm{~m}$ dan tidak dapat dijadikan sebagai tolak ukur kecerahan air dengan baku mutu air laut. Semua titik stasiun pengamatan yang terdapat breakwater berada pada kedalaman $3 \mathrm{~m}$, pada zona neritik (Sahami et al., 2014). Zona neritik secara horizontal meliputi wilayah pesisir pantai hingga kedalaman 200 m (Sahami et al., 2014). pH pada keenam stasiun berkisar dari 7-8, sehingga masih memenuhi baku mutu air laut untuk kehidupan biota. Kadar DO pada keenam stasiun menunjukan adanya variasi nilai antara 4.5-10.6 $\mathrm{mg} / \mathrm{L}$. Stasiun I, III dan IV memiliki nilai DO yang memenuhi baku mutu air laut. Sedangkan pada stasiun II, V dan VI memiliki nilai DO $<5$ yang berarti tidak memenuhi baku mutu air laut untuk biota pada umumnya. Salinitas pada enam stasiun menunjukan variasi nilai antara 30-34\%o dan masih berada pada kisaran nilai baku mutu. 
Tabel 4. Keberadaan tumbuhan lamun dan tipe substrat di setiap stasiun

\begin{tabular}{cccl}
\hline Stasiun & Transek & Lamun & \multicolumn{1}{c}{ Tipe Substrat } \\
\hline I & 1 & - & Berkarang \& Berbatu \\
& 2 & Ada & Berkarang, Berpasir \& Kasar Berbatu \\
II & 1 & - & Berkarang, Berpasir Kasar \& Berbatu \\
& 2 & Ada & Pasir Halus \& Berbatu \\
III & 1 & - & Pasir Halus \\
& 2 & - & Pasir Halus \& Berlumpur \\
IV & 1 & - & Berkarang \& Berpasir Halus \\
& 2 & - & Pasir Halus \& Berlumpur \\
V & 1 & - & Berbatu \& Berpasir Kasar \\
& 2 & - & Berbatu, Berpasir Kasar \& Berbatu \\
VI* & $1 *$ & Ada & Pasir Halus \\
\hline
\end{tabular}

Tipe substrat (Tabel 4) merupakan salah satu faktor fisik yang mempengaruhi struktur komunitas Polychaeta (Indarjo et al., 2005; Ni'amillah et al., 2012). Tekstur sedimen pasir yang didominasi oleh pasir kasar, memiliki produksi primer yang rendah (Erviani et al., 2015). Salah satu faktor yang juga mempengaruhi tipe substrat adalah kecepatan arus (Ridwan et al., 2016). Berdasarkan analisa dan pengukuran kecepatan arus, breakwater memberikan dampak yang signifikan. Kadar DO di stasiun III lebih tinggi dibandingkan stasiun lainnya yaitu 10,6 $\mathrm{mg} / \mathrm{L}$. Substrat yang memiliki tipe sedimen berpasir memiliki DO relatif lebih besar dibandingkan dengan tipe sedimen yang lebih halus seperti lumpur (Rohmadhoni dan Aunurohim, 2013). DO merupakan salah satu faktor yang mempengaruhi tingginya nilai keanekaragaman, kemerataan dan kepadatan di stasiun III.

Fenomena menarik tampak saat proses sampling di stasiun-stasiun yang terdapat breakwater ternyata area yang terjadi sedimentasi tidak ditemukan Polychaeta. Sebagian besar plot yang kosong (transek 2) merupakan daerah yang terjadi sedimentasi. Polychaeta cenderung memilih habitat tidak dinamis (stabil) dan tidak mengalami tekanan llingkungan yang dapat mengganggu kelangsungan hidupnya (Indarjo $e t$ al., 2005).

Daerah yang terjadi sedimentasi merupakan daerah yang tidak stabil, sehingga tidak ditemukan Polychaeta (Indarjo et al., 2005). Sedimentasi menjadi penghalang (barrier) bagi Polychaeta. Ruang-ruang dalam habitat untuk dieksploitasi oleh Polychaeta menjadi berkurang, sehingga persaingan antar individu maupun species relatif tinggi. Species Polychaeta yang ditemukan adalah indikasi bahwa species tersebut memiliki daya adaptasi dan survive yang baik (Indarjo et al., 2005; Ni'amillah et al., 2012), sehingga mampu mentolerir perubahan biologi, fisika dan kimia yang terjadi akibat adanya breakwater.

Plot-plot yang kosong pada transek 1 dipengaruhi oleh kondisi substrat yang kurang mendukung sebagai tempat hidup Polychaeta (Indarjo et al., 2005; Ni'amillah et al., 2012), serta juga dipengaruhi oleh kecepatan arus. Kecepatan arus di transek 1 relatif lebih tinggi dibanding dengan kecepatan arus di transek 2 . Daerah di sisi depan breakwater merupakan daerah yang terkena energi gelombang sangat besar, karena gelombang langsung pecah (direduksi). Hal ini menyebabkan daerah di sisi depan breakwater menjadi tidak stabil dan mempengaruhi kehidupan biota di sekitar, khususnya Polychaeta.

Data fisik dan kimia perairan (suhu, kecepatan arus, DO dan salinitas) digunakan untuk uji ANOVA dan uji BNt sedangkan biologis (indeks keanekaragaman, indeks kemerataan, kepadatan dan dominasi). Berdasarkan analisis ANOVA satu arah (single factor) (Wahab et al., 2018) terhadap faktor lingkungan diperoleh hasil yaitu $\mathrm{f}_{\text {hitung }}=6.81>$ $\mathrm{f}_{\text {tabel }}=3.09$ dan indikasi biologis yaitu $\mathrm{f}_{\text {hitung }}=3.26$ $>\mathrm{f}_{\text {tabel }}=3.09$. Data analisis ANOVA digunakan untuk uji lanjutan yaitu uji BNt dengan taraf kepercayaan 5\%. Stasiun III (terdapat bangunan breakwater) dan stasiun VI (tidak ada breakwater) baik digunakan sebagai pembanding 
karena merupakan stasiun yang memiliki faktor lingkungan dan indikasi biologis relatif baik dibandingkan stasiun yang terdapat breakwater lainnya.

Nilai uji BNt 5\% terhadap faktor lingkungan di keenam stasiun diperoleh nilai 1.603 dan indikasi biologis adalah 0.100 . Nilai yang diperoleh dari uji BNt 5\% mengindikasikan bahwa secara statistik, breakwater berdampak terhadap faktor lingkungan (fisik dan kimia), dan indikasi biologis Polychaeta (Tabel 5 dan 6). Berdasarkan nilai pada uji BNt terhadap faktor lingkungan, suhu, kecepatan arus dan DO di stasiun I, II, IV, V, dan VI menunjukan tidak berbeda signifikan, terkecuali di stasiun III. Sedangkan salinitas di stasiun III berbeda signifikan dengan stasiun II, IV, V dan VI. Salinitas di stasiun III dan stasiun II, IV, V, VI serta berbeda signifikan dengan stasiun I.
Berdasarkan nilai uji BNt 5\% terhadap indikasi biologis, indeks keanekaragaman, indeks kemerataan, kepadatan dan dominasi menunjukan nilai yang bervariasi. Keanekaragaman di stasiun I dan V tidak menunjukan perbedaan yang signifikan, jika didasarkan pada parameter perairan yang juga tidak berbeda signifikan. Parameter perairan (suhu, kecepatan arus dan DO) di stasiun I dan V tidak berbeda signifikan, terkecuali salinitas. Namun, stasiun I dan V berbeda siginifikan terhadap stasiun IV, II, VI dan III. Stasiun IV berbeda signifikan dengan stasiun I dan V, stasiun II, VI dan III. Stasiun II berbeda signifikan dengan stasiun I dan V, stasiun IV, VI dan III. Stasiun VI berbeda signifikan dengan stasiun I dan V, stasiun IV, II dan III. Stasiun III berbeda signifikan dengan stasiun I dan $\mathrm{V}$, stasiun IV, II dan VI.

Tabel 5. Notasi uji BNt terhadap faktor lingkungan. Pangkat pada kolom yang sama menunjukan perbedaan yang signifikan

\begin{tabular}{ccccc}
\hline Stasiun & Suhu & $\begin{array}{c}\text { Kecepatan } \\
\text { Arus }\end{array}$ & DO & Salinitas \\
\hline I & $29.4^{\mathrm{a}}$ & $0.075^{\mathrm{a}}$ & $5.9^{\mathrm{a}}$ & $34^{\mathrm{c}}$ \\
II & $30.25^{\mathrm{a}}$ & $0.285^{\mathrm{a}}$ & $4.5^{\mathrm{a}}$ & $32^{\mathrm{b}}$ \\
III & $32.35^{\mathrm{b}}$ & $1.75^{\mathrm{b}}$ & $10.6^{\mathrm{b}}$ & $30^{\mathrm{a}}$ \\
IV & $30^{\mathrm{a}}$ & $1.5^{\mathrm{a}}$ & $5^{\mathrm{a}}$ & $32^{\mathrm{b}}$ \\
V & $29.7^{\mathrm{a}}$ & $0.245^{\mathrm{a}}$ & $4.95^{\mathrm{a}}$ & $33^{\mathrm{b}}$ \\
VI & $28.7^{\mathrm{a}}$ & $0.1^{\mathrm{a}}$ & $4.9^{\mathrm{a}}$ & $33^{\mathrm{b}}$ \\
\hline
\end{tabular}

Tabel 6. Notasi uji BNt terhadap indikasi biologis. Indeks keanekaragaman (H'), indeks kemerataan (J), kepadatan (D), dominasi (C). Pangkat pada kolom yang sama menunjukan perbedaan yang signifikan

\begin{tabular}{ccccc}
\hline Stasiun & $\mathrm{H}^{\prime}$ & $\mathrm{J}$ & $\mathrm{D}$ & $\mathrm{C}$ \\
\hline I & $0.450^{\mathrm{a}}$ & $0.650^{\mathrm{b}}$ & $0.666^{\mathrm{b}}$ & $0.722^{\mathrm{e}}$ \\
II & $0.735^{\mathrm{c}}$ & $0.669^{\mathrm{b}}$ & $0.888^{\mathrm{c}}$ & $0.593^{\mathrm{d}}$ \\
III & $1.676^{\mathrm{e}}$ & $0.861^{\mathrm{c}}$ & $2.444^{\mathrm{f}}$ & $0.247^{\mathrm{b}}$ \\
IV & $0.600^{\mathrm{b}}$ & $0.546^{\mathrm{b}}$ & $1.222^{\mathrm{d}}$ & $0.685^{\mathrm{d}}$ \\
V & $0.366^{\mathrm{a}}$ & $0^{\mathrm{a}}$ & $0.111^{\mathrm{a}}$ & $0.111^{\mathrm{a}}$ \\
VI & $1.127^{\mathrm{d}}$ & $0.700^{\mathrm{b}}$ & $1.777^{\mathrm{c}}$ & $0.437^{\mathrm{c}}$ \\
\hline
\end{tabular}

\section{Distribusi Spasial Polychaeta di Pesisir Pantai Manokwari}

Distribusi spasial Polychaeta di pesisir pantai Manokwari (Gambar 4) cukup luas. Hal ini didukung oleh ditemukannya species Polychaeta di setiap stasiun pengamatan. Polychaeta yang ditemukan ini didominasi oleh spesies Polychaeta pemakan deposit (deposit feeder). Polychaeta pemakan deposit memiliki karakteristik antena dan filament brancial pada bagian kepala. Substrat lumpur merupakan faktor yang berkontribusi terhadap keberadaan spesies Polychaeta ini. Distribusi spasial Polychaeta berkaitan erat dengan substrat dan juga kualitas 




Gambar 4. Distribusi spasial Polychaeta di pesisir pantai Manokwari

periaran (Sahidin dan Wardiatno, 2016).

Genus yang memiliki distribusi luas adalah Glycera, genus ini ditemukan di semua stasiun pengamatan. Species yang memiliki distribusi cukup luas adalah Glycera sp.2. Glycera sp.2 ditemukan pada stasiun II, III, IV dan VI. Keberadaan genus Glycera berkaitan erat dengan substrat lumpur, namun species seperti Glycera capitata juga berasosiasi dengan substrat berpasir (Sahidin dan Wardiatno, 2016). Distribusi yang luas juga mengindikasikan bahwa Polychaeta memiliki tingkat daya adaptasi dan survive yang sangat baik (Indarjo et al., 2005; Ni'amillah et al., 2012). Sedangkan, genus yang memiliki distribusi sempit adalah Arabella, Brada, Capitella, Exogonoides, Goniada, Notomastus, Onuphis, Sabella, Stygocapitella, Thelepus dan Thelotelepus.

Faktor biologi, fisika dan kimia perairan menjadi faktor pembatas dalam distribusi Polychaeta. Breakwater juga menjadi salah satu penghalang proses migrasi dan distribusi Polychaeta. Keberadaan breakwater mengubah sedimen dasar perairan yang berdampak pada distribusi Polychaeta. Daerah di sisi belakang breakwater yang terjadi sedimentasi, cenderung dijauhi Polychaeta karena pada daerah ini kondisi dasar perairan tidak stabil (Indarjo et al., 2005). Polychaeta cenderung berada pada daerah-daerah yang tidak terjadi sedimentasi.

Keadaan lingkungan yang tertekan, hanya dapat dihuni oleh polychaeta yang bersifat opportunistic yang dapat mentolerir lingkungan yang kurang stabil dan pada beberapa jenis polychaeta tertentu dapat berkembang dengan baik sehingga akan mendominasi sedangkan beberapa jenis polychaeta yang lain tidak dapat hidup dan tumbuh dengan baik (Daeur, 1993).

\section{SIMPULAN}

Penelitian ini berhasil mendokumentasikan 17 species yang terbagi dalam tujuh ordo, sembilan familli dan 14 genus. Uji ANOVA dan Uji BNt menunjukan keselarasan bahwa pembangunan breakwater berdampak signifikan terhadap struktur komunitas Polychaeta. Tercatat 
spesies dari genus Glycera ditemukan di semua stasiun pengamatan, sedangkan genus yang memiliki distribusi terbatas pada satu stasiun adalah Arabella, Brada, Exogonoides, Goniada, Notomastus, Onuphis, Stygocapitella, Sabella, Thelepus dan Telothelepus.

\section{DAFTAR PUSTAKA}

Ariani FW, Zainuri M, Handoyo G. 2013. Studi Run-up Gelombang pada Offshore Breakwater di Pantai Slamaran Pekalongan. Jurnal Oseanografi 2(1): 1-8.

Daeur DM. 1993. Biological Criteria, Environmental Health and Estuarine Macrobenthic Community Structure. Marine Pollution Bulletin 26(5): 249-257.

Day JH. 1967. A Monograph on the Polychaeta of southern Africa, Part I (Errantia) \& Part II (Sedentaria). Trusteea of The British Museum (Natural History): London.

Erviani AE, Trijoko, Hasdisusanto S. 2015. Karakter Morfologi dan Substrat Polychaeta di Pantai Losari, Kota Makassar, Sulawesi Selatan. Jurnal Alam dan Lingkungan 6 (12): 29-35.

Fauchald K. 1977. The Polychaete Worm: Definitions and Keys to the Orders Families and Genera. Science Series 28. Natural History Museum: Los Angeles.

Gholizadeh M, Yahya K, Talib A, Ahmad O. 2012. Effects of Environmental Factors on Polychaete Assemblage in Penang National Park, Malaysia. International Journal of Environmental and Ecological Engineering 6 (12): 752-755.

Grzimek's Animal Life Encyclopedia, 2nd edition. 2004. Volume 2, Protostomes, edited by Michael Hutchins, Sean F. Craig, Dennis A. Thoney and Neil Schlager. Farmington Hills, MI: Gale Group. Canada.

Indarjo A, Widianingsih, Abdulah AB. 2005. Distribusi dan Kelimpahan Polychaeta di Kawasan Hutan Mangrove Klaces dan Sapuregel, Segara Anakan, Cilacap. Ilmu Kelautan 10 (1): 24-29.

Insafitri. 2010. Keanekaragaman, Keseragaman dan Dominansi Bivalvia di Area Buangan Lumpur Lapindo Muara Sungai Porong. Jurnal Kelautan 3(1): 54-59.
Junardi, Wardoyo ERP. 2008. Struktur Komunitas dan Karakteristik Substrat Cacing Laut (Polychaeta) di Perairan Pantai Mangrove Peniti, Kalimantan Barat. Biodiversitas 9 (3): 213-216.

Kari EE. 2002. Soft Sediment Benthic Biodiversity on The Continental Shelf in Relation to Environmental Variability. Marine Ecology Progress Series 232: 15-27.

Keputusan Menteri Negara Lingkungan Hidup Nomor 51. 2004. Baku Mutu Air Laut untuk Biota Laut. Kementerian Lingkungan Hidup: Jakarta.

Mentarijuita R, Soenardjo N, Riniatsih I. 2014. Kajian Keberadaan Komunitas Makrozoobenthos pada Kondisi Ekosistem Mangrove yang Berbeda di Pesisir Semarang. Journal of Marine Research 3 (3): 314-323.

Moore J. 2006. An Introduction to the Invertebrates. 2nd Edition. Cambridge University Press: New York.

Munairi A, Abida IW. 2012. Studi Kepadatan dan Pola Distribusi Cacing Lur (Nereis sp.) di Perairan Pesisir Kecamatan Kwanyar Kabupaten Bangkalan. Jurnal Kelautan 5 (1): 47-57.

Murugesan P, Pravinkumar M, Muthuvelu S, Ravichandran S, Vijayalakshmi S, Balasubramanian T. 2016. Benthic Biodiversity in Natural Vis-a-vis Artificially Developed Mangroves of South East Coast of India. Indian Journal of Geo-Marine Sciences 45 (8): 1049-1058.

Ni'amillah, Pribadi R, Djunaedi A. 2012. Struktur Komunitas Makrobentos Polychaeta di Ekosistem Mangrove Desa Bedono Kecamatan Sayung Kabupaten Demak. Journal of Marine Research 1(1): 54-61.

Priyandayani LPt, Hendrawan IG, Karim W. 2017. Kelimpahan dan Keanekaragaman Polychaeta pada Jenis Mangrove yang Berbeda di Tahura Ngurah Rai. Journal of Marine and Aquatic Sciences 4 (2): 171-178. Putra AOP, Armono HD, Sujantoko. 2013. Pengaruh Elevasi Muka Air Laut pada Koefisien Transmisi dan Refleksi Composite Breakwater. Jurnal Teknik Pomits 2 (1): 4751.

Qudratullah H, Setyawati TR, Yanti AH. 2013. 
Keanekaragaman Cacing Tanah (Oligochaeta) pada Tiga Tipe Habitat di Kecamatan Pontianak Kota. Jurnal Protobiont 2 (2): 5662.

Rasidi. 2012. Pembenihan cacing laut Dendronereis pinnaticirris: Sauatu upaya awal penyediaan benih cacing laut untuk budidaya. Media Akuakultur 7 (2): 88-91.

Refi A. 2013. Analisis Break Water pada Pelabuhan Teluk Bayur dengan Menggunakan Batu Alam, Tetrapod dan Ajack. Jurnal Momentum 15 (2): 1-14.

Ridwan M, Fathoni R, Fatihah I, Pangestu DA. 2016. Struktur Komunitas Makrozoobenthos di Empat Muara Sungai Cagar Alam Pulau Dua, Serang, Banten. Al-Kauniyah Jurnal Biologi 9 (1): 57-65.

Romadhoni M, Aunurohim. 2013. Struktur Komunitas Polychaeta Kawasan Mangrove Muara Sungai Kali Lamong-Pulau Galang, Gresik. Jurnal Sains dan Seni Pomits 2 (2): 212-218.

Romimohtarto K, Juwana S. 2007. Biologi Laut: Ilmu Pengetahuan Tentang Biota Laut. Edisi 3 (edisi revisi). Percetakan Ikrar Mandiriabadi: Jakarta.

Sahami FM, Hamzah SN, Panigoro C, Hasim. 2014. Lingkungan Perairan dan Produktivitasnya. Edisi I. Deepublish: Yogyakarta.

Sahidin A, Wardiatno Y. 2016. Distribusi Spasial Polychaeta di Perairan Pesisir Tangerang, Provinsi Banten. Jurnal Perikanan dan Kelautan 6 (2): 83-94.

Satrya C, Yusuf M, Shidqi M, Subhan B, Arafat D, Anggraeni F. 2012. Keragaman Lamun di
Teluk Banten, Provinsi Banten. Jurnal Teknologi Perikanan dan Kelautan 3 (1): 2934.

Shin PKS, Huang ZG, Wu RSS. 2004. An Update Baseline of Subtropical Macrobenthic Communities in Hong Kong. Marine Pollution Bulletin 49: 119-141.

Sundaravarman K, Varadharajan D, Babu A, Saravanakumar A, Vijayalakshmi S, Balasubramania T. 2012. A Study of A Marine Benthic Fauna with Special Reference to the Environmental Parameters, South East Coastal of India. International Journal of Pharmaceutical and Biological Archives 3 (5): 1157-1169.

Tobing ISL. 2009. Kondisi Perairan Pantai sekitar Merak, Banten Berdasarkan Indeks Keanekaragaman Jenis Benthos. Vis Vitalis 2 (2): 31-40.

Tomassetti P, Porrello S. 2005. Polychaetes as Indicators of Marine Fish Farm Organic Enrichment. Aquaculture International 13: 109-128.

Wahab I, Kawaroe M, Madduppa H. 2018. Perbandingan Kelimpahan Makrozoobentos di Ekosistem Lamun pada Saat Bulan Purnama dan Perbani di Pulau Panggang Kepulauan Seribu Jakarta. Jurnal Ilmu dan Teknologi Kelautan Tropis 10 (1): 217-229.

Wowor NM, Kaligis FG, Paruntu C. 2016. Struktur Komunitas Meiofauna pada Hutan Mangrove di Pesisir Dusun Kuala Batu Kecamatan Likupang Timur Kabupaten Minahasa Utara. Jurnal Pesisir dan Laut Tropis 1 (1): 1-8. 